\title{
Evaluating the Effect of Cultivars and Seeding Rates on the Yield of Lentil Grown under the Vertisols Production System
}

\author{
Mebrate Tamrat Woldeselassie (D), ${ }^{1}$ Abel Gizaw, ${ }^{2}$ and Simegnew Aniley ${ }^{2}$ \\ ${ }^{1}$ Crop Research Directorate, Holetta Agricultural Research Center, P.O. Box 2003, Addis Ababa, Ethiopia \\ ${ }^{2}$ Crop Research Directorate, DebreBirhan Agricultural Research Center, P.O. Box 112, Debre Birhan, Ethiopia \\ Correspondence should be addressed to Mebrate Tamrat Woldeselassie; mebtam@gmail.com
}

Received 16 February 2021; Revised 23 October 2021; Accepted 30 December 2021; Published 31 January 2022

Academic Editor: Othmane Merah

Copyright ( $) 2022$ Mebrate Tamrat Woldeselassie et al. This is an open access article distributed under the Creative Commons Attribution License, which permits unrestricted use, distribution, and reproduction in any medium, provided the original work is properly cited.

\begin{abstract}
Lentil is the second leading pulse crop grown in the central highland Vertisols of Ethiopia. However, waterlogging and the lack of situation-specific seed rate recommendations are among the problems that constrain its productivity. Therefore, a field experiment was conducted during 2017 and 2018 to determine the economically optimum seed rate for broadcast sowing of lentil varieties on Vertisols of North Shewa. Factorial combinations of two varieties of lentils ("Derash," large-seeded and "Local cultivar," small-seeded) and six seed rates (40,60, 80, 100, 120, and $140 \mathrm{~kg} / \mathrm{ha}$ ) were tested in RCBD. According to the ANOVA results, the main effects of the environment, variety, and seed rate showed a significant effect on most parameters considered, except hundred seed weight for the environment, the number of seeds per pod for variety and plant height, and hundred seed weight for the main effect of seed rate. Lower yields were obtained in the second year due to the occurrence of sporadic unidentified disease, which might have created a confounding effect with variations due to the environment. The grain yield of variety "Derash" was best fitted to a power function, whereas "Local cultivar" showed a quadratic response with increasing seed rates ranging from 40 to $140 \mathrm{~kg} / \mathrm{ha}$. There was a positive and significant $(p<0.001)$ correlation between grain yield and each of the following: plant height, number of pods per plant, number of seeds per pod, and 100-seed weight. Based on ANOVA and economic analysis results, a seed rate of $100 \mathrm{~kg} / \mathrm{ha}$ was found to be optimum for both varieties under the broad bed and furrow production systems on Vertisols.
\end{abstract}

\section{Introduction}

One of the oldest cultivated legume crops is lentils (Lens culinaris Medic.). Due to its valuable chemical composition and health-promoting properties, it is a desirable element of an everyday diet. Lentil seeds contain $24-32 \%$ of valuable protein and are also a rich source of phytoestrogens, folic acid, group B vitamins, and micronutrients [1]. In Ethiopia, it covers about $7.46 \%$ of the total pulse area and provides $5.88 \%$ of the pulse production [2]. It is almost a cash crop because it fetches very high prices compared with all other food legumes and main cereal crops such as tef, wheat, and barley [3]. The demand for this commodity, both in local and international markets, has increased significantly in recent years. It is often claimed that the internal (local) market seriously competes with the external market [4]. Moreover, it offers an additional advantage emanating from its unique properties in restoring and maintaining soil fertility through symbiotic biological nitrogen fixation. Lentil can fix up to $107 \mathrm{~kg}$ of N/ha, implying a fixation of about 6,500 tons of N annually in Ethiopia. Consequently, Ethiopian lentil culture is characterized by growing the crop mainly in rotation with major cereals such as tef wheat, barley, and others. In such a culture, the yield advantage of the succeeding cereal crop is realized because of the fixed nitrogen by the predecessor legume and due to the breakage of the life cycle of important diseases and insect pests [5]. However, its average grain yield has remained low $(1.37 \mathrm{t} / \mathrm{ha}$ ) compared to $2.16 \mathrm{t} / \mathrm{ha}$ for faba beans and $2.01 \mathrm{t} / \mathrm{ha}$ for chickpeas (average of red and white types) [2]. This is due to several biotic factors (insects, diseases, and weeds) and abiotic factors (temperature, soil fertility, drought, waterlogging, and frosts) which affect the 
production of lentils [5]. Waterlogging on Vertisols and a lack of specific plant density/seed rate recommendations are among the major yield-limiting constraints of the study areas. Moretina Jiru and Siyadebrina Wayu districts are among the areas where heavy clay soil (Vertisols) is dominant. In these areas, rainfall is high and the waterlogging problem is also more intense [6]. Therefore, waterlogging during the growing season impedes the performance of crops. Traditionally, farmers have been using handmade broad beds and furrows (HBBF-locally known as "Zekosh") to solve the waterlogging problem, though its high labor requirement is a constraint to its wider application. Studies on Vertisols indicated that draining excess water using broad bed and furrow (BBF) in Ethiopia resulted in increased yields of crops grown on Vertisols compared to flat-seeded [7]. According to Agegnehu [8], planting of lentils on BBF resulted in $106 \%$ grain yield and $78 \%$ straw yield increments over flatbed planting.

However, unlike flatbed practice under drained soil conditions, the production of crops under the BBF production system forces farmers to leave one-third of the land uncultivated for drainage purposes. Hence, this may require the recommendation of a specific seed rate (plant density) for lentil production under the BBF drainage system. It is also to be noted that the response to plant density varies among lentil genotypes/varieties depending on the seed size and growth habit of the specific cultivars [5]. For example, erect-growing and large-seeded genotypes need a higher seed rate, whereas prostrate and small-seeded ones need relatively lower seed rates [5]. Accordingly, several recommendations have been made within the country and around the globe to achieve optimum plant density. Saleem et al. [9] recommended a seed rate of $40-45 \mathrm{~kg} / \mathrm{ha}$ for the production of small-to medium-sized lentil varieties around Islamabad and adjacent areas. On the other hand, Singh et al. [10] noted that, on average, sowing rates of 60 and $80 \mathrm{~kg} / \mathrm{ha}$ increased the grain yield by $17 \%$ and $15 \%$, respectively, over $40 \mathrm{~kg} / \mathrm{ha}$. Similarly, Morrison and Muehlbauer [11] recommended a seeding rate ranging from 67 to $79 \mathrm{~kg} / \mathrm{ha}$ for the most commonly grown cultivar, "Brewer," for Palouse farmers in Washington State, the USA. In another study conducted in Southern Australia, a plant density of about 150 plants per square meter using a sowing rate of about $90-110 \mathrm{~kg} / \mathrm{ha}$ was recommended depending on seed size and germination percentage of the seed [12]. In general, depending upon seed size, growth habit, planting time, and growing conditions, variable lentil sowing rates have been recommended around the globe, ranging from $20 \mathrm{~kg} / \mathrm{ha}$ for a very small-seeded in Bangladesh [9] to $110 \mathrm{~kg} / \mathrm{ha}$ for a largeseeded in Southern Australia [12]. However, according to a review by Saleem et al. [9], many studies show that lentil yields are remarkably stable over a wide range of population densities due to the ability of the plants to fill available space by initiating lateral branches and, thus, can compensate for poor emergence and thin stands.

For the sowing of lentils in rows in Ethiopia, a spacing of $20-25 \mathrm{~cm}$ between rows and $2.5-5.0 \mathrm{~cm}$ between plants has been recommended. On the other hand, the seed rate for the broadcast method appeared to vary depending on seed size and growth habits. Accordingly, a larger seed size requires higher seed rates than a smaller seed size. Thus, a seed rate of $50-65 \mathrm{~kg} / \mathrm{ha}$ for small-seeded, $65-80 \mathrm{~kg} / \mathrm{ha}$ for mediumseeded, and up to $80-120 \mathrm{~kg} /$ ha for large-seeded lentil cultivars has been recommended on a blanket basis [13]. However, farmers in the study area are using higher seed rates $(>100 \mathrm{~kg} / \mathrm{ha}$ for all varieties) than the blanket recommendations. This is probably related to the absence of recommendations for broadcast planting of lentils on a broad bed and furrow production system where more field loss is expected. In addition, recommending the optimum seed rate for both large and small-seeded lentil varieties produced on Vertisols is crucial as they have different merits. The "Local cultivar" (small seed size) is preferred to prepare traditional food known as "Misir wot" or lentil stews (prepared from decorticated and split grains), as it tolerates higher heat than the improved variety "Derash" (large seed size) (personal communication). Hence, it is more preferred in the domestic market and fetches higher prices, while the improved variety is largely meant for the international market as it has a large seed size (personal communication). Therefore, these issues may necessitate the development of recommendations specific to heavy Vertisols. As a result, this study was initiated to determine the economically optimum seed rate for a broadcast sowing of lentil varieties on North Shewa Vertisols.

\section{Materials and Methods}

2.1. Site Description. Field experiments were conducted for two years (2017 and 2018) in Moretina Jiru and Siyadebrina Wayu districts, about $192 \mathrm{~km}$ and $177 \mathrm{~km}$ north of Addis Ababa, respectively, on relatively light and heavy Vertisol types as determined by farmers' experience during the main rainy season (from July to December). The experimental sites were located at latitudes ranging from $9^{0} 48^{\prime} \mathrm{N}$ to $9^{0} 53^{\prime} \mathrm{N}$, longitudes ranging from $39^{0} 10^{\prime} \mathrm{E}$ to $39^{\circ} 12^{\prime} \mathrm{E}$, and altitudes ranging from 2642 to 2665 meters above the sea level [14], as well as on-site records at Siyadebrina Wayu district). The sites were representative of the soils and environmental conditions used for lentil production in the recommendation domain.

\subsection{Experimental Design, Treatments, and Plot Management.} The treatments included a factorial combination of two varieties/cultivars of lentil ("Derash" and "Local cultivar") having different seed sizes (a 100-seed weight of about $3.42 \mathrm{~g}$ and $2.88 \mathrm{~g}$, respectively) and six seed rates $(40,60,80,100$, 120 , and $140 \mathrm{~kg} / \mathrm{ha}$ ). Accordingly, a $2 \times 6$ complete factorial experiment was conducted in a randomized complete block design (RCBD) with three replications. A gross plot size of $4 \mathrm{~m}$ long and $4.8 \mathrm{~m}$ wide $\left(19.2 \mathrm{~m}^{2}\right)$ was used. Two central beds (a net plot area of $9.6 \mathrm{~m}^{2}$ ( $4 \mathrm{~m}$ long and $2.4 \mathrm{~m}$ wide)) were used for agronomic data collection and grain yield measurement. The space between replications and plots was maintained at $1.5 \mathrm{~m}$ and $1 \mathrm{~m}$, respectively. Broadcast planting was exercised using a handmade broad bed and furrow (traditionally used by farmers) drainage system. In 
this practice, raised beds of about $80 \mathrm{~cm}$ wide, separated by furrows of $40 \mathrm{~cm}$ wide and $15 \mathrm{~cm}$ deep, were established. This drainage system was done by the hand without the help of any tool, except that a dual oxen-drawn plow, the "Maresha," was used to open furrows at about every $1.2 \mathrm{~m}$ wide intervals. Handmade broad beds and furrows were made by the following sequential operations: first seeds were broadcast on the flat seedbed for each seed rate level in each plot, furrows were opened at every $1.2 \mathrm{~m}$ wide intervals using an oxen-drawn plow, and the soil was scooped out by the hand from the furrows to cover the seeds on the bed [15]. By doing so, four raised beds of about $80 \mathrm{~cm}$ wide, separated by furrows of $40 \mathrm{~cm}$ wide and $15 \mathrm{~cm}$ deep, were established in each plot. At the time of sowing, NPS chemical fertilizer at a rate of $121 \mathrm{~kg} / \mathrm{ha}$ was applied uniformly to all experimental plots. Twice-hand weeding was undertaken to control weeds. Insect pests (aphids) were controlled by applying insecticides. Sowing was undertaken from the end of June to midAugust, while harvesting was undertaken from the end of December to mid-January in both years.

2.3. Sampling and Analysis of Soil. A composite soil sample was collected from five spots of the whole experimental field in a zigzag pattern from a depth of $0-30 \mathrm{~cm}$ before sowing. The sample was analyzed for selected physicochemical properties, mainly textural class (percent sand, silt, and clay), soil $\mathrm{pH}$, total nitrogen, organic matter content, available phosphorus, and cation exchange capacity (CEC). The textural class was analyzed by the hydrometer method [16]. Soil reaction $(\mathrm{pH})$ was tested by the potentiometric method [17]. Organic matter (OM) was determined by the Walkley and Black method [17]. A cation exchange capacity (CEC) was determined by a flame photometer [16]. Total $\mathrm{N}$ was determined using the Kjeldahl method [17], available $\mathrm{P}$ was determined using the Olson method [17], and exchangeable $\mathrm{K}$ was determined by a flame photometer [18].

2.4. Data Gathering and Measurements. Data collected on yield and yield-related traits consisted of days to flowering, days to physiological maturity, plant height, number of pods per plant, number of seeds per pod, 100-seed weight, and grain yield. Days to flowering were recorded when $50 \%$ of the plants in the plot produced their first flower, while days to physiological maturity were recorded when $90 \%$ of the plants in the plot reached physiological maturity. On the other hand, plant height, number of pods per plant, and number of seeds per pod were measured from 10 randomly selected plants from the central two beds of each plot. Plant height was measured in $\mathrm{cm}$ from the ground to the tip of the main stem at $90 \%$ physiological maturity. The number of pods per plant and the number of seeds per pod were measured at the time of harvest from 10 randomly selected plants. Grain yield was measured from the two central beds of each plot, while 100-seed weight was measured in grams as an average of two randomly counted 100-seed samples from each net plot after sun drying of threshed seeds.
2.5. Statistics, Regression, and Economics Analysis. Analysis of variance (ANOVA) was performed using GenStat version 16 and/or SAS Software version 9.0 [19]. The mean comparison was performed using Duncan's multiple range test (DMRT) at a 5\% level of significance upon obtaining significant $F$ values for the factors and interactions. The two-year data, i.e., three sites in 2017 and 2 sites in 2018 (mentioned as environments hereafter), were combined after obtaining variance homogeneity, which was tested by employing Bartlett's test [20].

The regression of grain yield of lentil varieties on seed rate was analyzed to see their relationship and fit the response curve. The curve fit was achieved by employing a stepwise selection technique (using polynomial terms) [20].

The economic analysis was performed on the mean predicted values of grain yield (derived from the fitted regression equation) following the methods of CIMMYT [21]. The field price was obtained by a simple assessment of farm gate prices near the experimental field immediately after harvest (December-February), which was taken as an average of two years. Accordingly, the prices of grain yield of "Derash" and "Local cultivar" were Ethiopian Birr (ETB) 28.00 and 30.00 per $\mathrm{kg}$, respectively. The variable costs included the cost of seed during sowing (August) and were estimated at ETB 29.00 and 31.00 per kg for "Derash" and "Local cultivar," respectively. The cost of NPS fertilizer was not considered because it was applied uniformly to all plots [21]. The cost of labor for weeding, harvesting, threshing, winnowing, packing, and transporting of each treatment was not considered because of the difficulty in estimating it as the experiment was done on a small plot [21], and the differences were assumed to be negligible [22]. The average yield was adjusted downward to $10 \%$, assuming a yield reduction of $10 \%$ if farmers managed the same on a larger plot. To use the marginal rate of return (MRR) as a basis for variety and seed rate recommendations, the minimum acceptable rate of return was set at $75 \%$ for both varieties/cultivars [21]. Treatment with higher costs that vary and lower net benefit than the preceding treatment was considered dominated and was eliminated from further consideration [21].

\section{Results and Discussion}

3.1. Experimental Sites' Soil Physicochemical Properties. As given in Table 1, the soil analysis of the study sites/environments revealed that the surface soil of all experimental fields was clay in texture. On average, the environments/sites were slightly acidic in $\mathrm{pH}$ (6.467), low in organic matter $(1.23 \%)$, low in total nitrogen content $(0.0803 \%)$, medium to high in exchangeable potassium $(0.637 \mathrm{cmol}(+) / \mathrm{kg}$ soil $)$, and high in cation exchange capacity $(31.67 \mathrm{cmol}(+) / \mathrm{kg}$ soil $)$ (soil lab results from Debre Berhan Agricultural Research Center, 2017).

3.2. Weather Conditions during the Crop's Growth Period. According to the unpublished data of the Ethiopian National Metrological Agency [22], the rainfall distribution and amount were lower for the year $2017(676.1 \mathrm{~mm})$ than for the 
TABLe 1: Soil analysis results of Enewari and Deneba areas for the year 2017.

\begin{tabular}{|c|c|c|c|c|c|c|}
\hline \multicolumn{2}{|l|}{ Parameter } & Burtilik site & \multirow{2}{*}{$\frac{\text { Deneba site }}{68}$} & \multirow{2}{*}{$\frac{\text { Farmer field }}{68}$} & \multirow{2}{*}{$\begin{array}{c}\text { Mean value }(\text { mean } \pm \mathrm{SE}) \\
68.67 \pm 0.667\end{array}$} & Rating/soil reaction class \\
\hline \multirow{3}{*}{ Soil texture (\%) } & Clay & 70 & & & & \\
\hline & Sand & 10 & 12 & 14 & $12 \pm 1.155$ & \\
\hline & Silt & 20 & 20 & 18 & $19.33 \pm 0.667$ & \\
\hline & Clay & Clay & Clay & Clay & Clay \\
\hline & $\mathrm{pH}\left(1: 2.5 \mathrm{H}_{2} \mathrm{O}\right)$ & 6.36 & 6.60 & 6.44 & $6.467 \pm 0.0706$ & Slightly acidic \\
\hline \multicolumn{2}{|l|}{$\mathrm{OM}(\%)$} & 1.03 & 1.64 & 1.02 & $1.23 \pm 0.206$ & Low \\
\hline \multicolumn{2}{|l|}{$\mathrm{TN}(\%)$} & 0.074 & 0.094 & 0.073 & $0.0803 \pm 0.00678$ & Low \\
\hline \multicolumn{2}{|l|}{ Av. P (ppm) } & n.d & n.d & n.d & n.d & n.d. \\
\hline \multicolumn{2}{|c|}{ Ex. K (cmol(+)/kg soil) } & 0.59 & 0.63 & 0.69 & $0.637 \pm 0.0296$ & $\begin{array}{l}\text { Medium (at Burtilik) to high } \\
\text { (at Deneba and farmer field) }\end{array}$ \\
\hline \multicolumn{2}{|c|}{$\mathrm{CEC}(\mathrm{cmol}(+) / \mathrm{kg}$ soil $)$} & 35.50 & 29.60 & 29.92 & $31.67 \pm 1.916$ & High \\
\hline
\end{tabular}

SE, standard error of the mean; OM, organic matter; n.d, not determined; TN, total nitrogen; Av.P, available phosphorus; Ex. K, exchangeable K; CEC, cation exchange capacity. Source: Debre Berhan Agricultural Research Center Laboratory result.

year 2018 (772.2 mm). In 2018, there was rainfall from July to November with a decreasing trend, while there was no (negligible) rainfall after September in 2017 (Figure 1). Accordingly, the year 2018 seemed more favorable for lentil production, despite the damage caused by sporadic unidentified disease, which resulted in lower yields. The maximum temperature was higher in 2018 than in 2017 (except for July), and both showed an increasing trend after October (Figure 1). The mean minimum temperature showed a decreasing trend from August to December for 2018, while it lacked a trend for 2017 (Figure 1) [22].

3.3. Grain Yield and Agronomic Traits. As stated in the methodology section, five environments (where environment one is denoted by the Burtilik site in 2017, environment two is denoted by the Deneba site in 2017, environment three is denoted by the farmer's field in 2017, environment four is denoted by the Burtilik site in 2018, and environment five is denoted by the Deneba site in 2018) were considered for the analysis and interpretation of the data.

3.3.1. Grain Yield. As given in Table 2, ANOVA results showed a significant $(p<0.05)$ effect on the main effects of the environment, variety, and seed rate, as well as on the twoway interaction of the environment by variety, environment by seed rate, and on the three-way interaction of environment by variety by seed rate. The interactions with the environment (three-way and two-way) seemed highly significant, probably due to a confounding effect of the unidentified disease (that was identified as a viral disease after harvesting of the crop) problem in addition to environmental effects.

The three-way interaction was interpreted using the approaches suggested by Gomez and Gomez ([20], p.618). Accordingly, for the variety "Derash," both the highest and the lowest grain yield were recorded at the Deneba site in 2017 and 2018, respectively, at a seed rate of $120 \mathrm{~kg} / \mathrm{ha}$, while for the "Local cultivar," the highest grain yield was recorded at the Deneba site in 2017 at a seed rate of $140 \mathrm{~kg} / \mathrm{ha}$ and the lowest grain yield was recorded at the Burtilik site in 2018 at a seed rate of $40 \mathrm{~kg} / \mathrm{ha}$ (Figure 2). In general, for both varieties, the highest grain yield was recorded in the first year at both localities and the lowest grain yield was obtained in the second year, while the farmer's field lies in between the two (Figure 2). The lower yields in the second year (2018) were probably related to the negative effect of the unidentified disease problem that occurred at both localities, affecting both varieties equally rather than the year effect [20]. If not, there was a higher and evenly distributed amount of rainfall in 2018, which might be favorable for the production of higher grain yields (Figure 1). The Deneba site, with its lower clay content, higher $\mathrm{pH}$, higher $\mathrm{OM}$, and higher total nitrogen, seemed to have more potential for lentil production (Table 1 and Figure 2).

Although the interaction between variety and seed rate was nonsignificant, stepwise polynomial regression chose a quadratic term for the variety "Local cultivar," while the variety "Derash" was the best fitted using the power function rather than linear regression due to a higher $R^{2}$ value $\left(0.90^{* *}\right)$ for the power function (Figure 3 ). The equation became significant, probably due to varietal differences given in Table 2. In a similar experiment, Molla [23] fitted a significant stepwise regression equation, having significantly predicted terms for the nonsignificant NP interaction in the wheat fertilizer experiment. Based on the economic analysis results obtained from the predicted values obtained from a power function (Figure 3), a linear increase was observed for the variety "Derash," although it was not economical after a seed rate of $100 \mathrm{~kg} / \mathrm{ha}$ (Table 3 ). At this seed rate, a net benefit of Ethiopian Birr 30379.52 and an MRR of $77.56 \%$ was obtained, while the minimum acceptable rate of return was set at $75 \%$. On the other hand, the economic analysis for the "Local cultivar" was done using the predicted values obtained from a quadratic equation (Figure 3). Accordingly, the highest economic returns were obtained at a seed rate of $100 \mathrm{~kg} / \mathrm{ha}$ with a net benefit of Ethiopian Birr 29732.00 and MRR of $108.60 \%$, while the minimum acceptable rate of return was set at $75 \%$ (Table 4 ). In a similar manner, the mean grain yield across the varieties showed an increasing trend (by 28.04\%) as the seed rate increased from 40 to $140 \mathrm{~kg} / \mathrm{ha}$, though it was insignificant from 100 to $140 \mathrm{~kg} /$ ha (Table 5).

Hence, depending on the ANOVA and economic analysis results, a similar seed rate of $100 \mathrm{~kg} / \mathrm{ha}$ could be recommended for both varieties. In line with this result, 


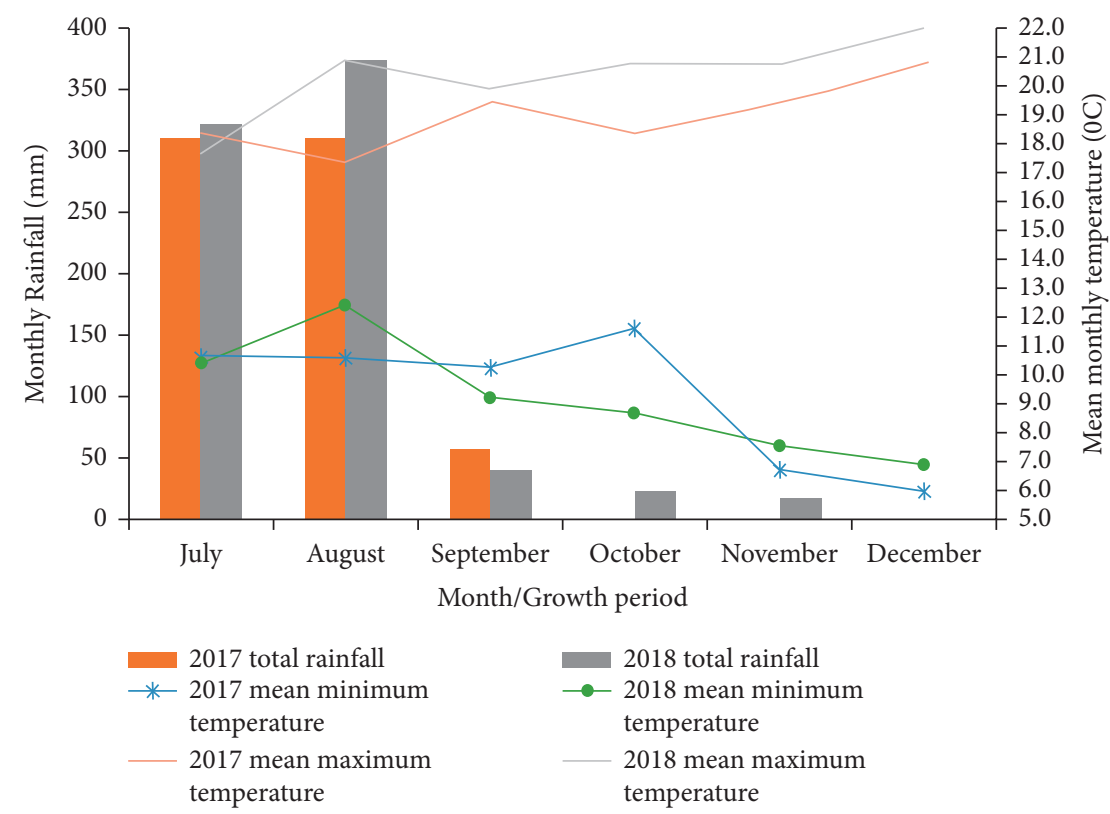

Figure 1: Rainfall $(\mathrm{mm})$ and minimum and maximum temperatures for the growth period of lentils at Enewari. Source: National Meteorology Agency, Kombolcha branch directorate (unpublished data).

TABLE 2: Mean square values of ANOVA for grain yield of lentil as affected by variety/cultivar and plant density at Moretina Jiru and Siyadebrina Wayu districts, combined over five environments in 2017 and 2018.

\begin{tabular}{lcc}
\hline Source of variation & d.f. & Grain yield \\
\hline Replication (R) & 2 & 0.15804 \\
Environment (Env) & 4 & $8.15999^{* *}$ \\
Variety (Var) & 1 & $0.38617^{* *}$ \\
Seed rate (Sr) & 5 & $0.33773^{* *}$ \\
Env.Var & 4 & $0.53771^{* *}$ \\
Env.Sr & 20 & $0.09121^{*}$ \\
Var.Sr & 5 & $0.01431 \mathrm{~ns}^{*}$ \\
Env.Var.Sr & 20 & $0.10553^{* *}$ \\
Pooled error & 118 & 0.04935 \\
\hline
\end{tabular}

Siddique et al. [12] recommended a seed rate of $90-110 \mathrm{~kg} /$ ha in Southern Australia, depending on seed size and germination percentage of lentil seeds. The present results could also agree with the actual farmers' practice in those localities where they use higher seed rates $(>100 \mathrm{~kg} / \mathrm{ha}$ for all varieties) than the blanket recommendations mentioned in Mitiku [13].

3.3.2. Growth Parameters, Phenological Characteristics, and Yield Components. As was the case with grain yield, the environment showed a significant effect on most parameters considered, except 100-seed weight (Table 5). There was an extended flowering and maturity period in 2018 at Burtilik and Deneba sites that was probably attributed to higher and evenly distributed rainfall throughout the growth period of the lentil crop (Figure 1). Shorter plants were observed in 2018 at both the Burtilik and Deneba sites, probably due to the stunting effect of the disease (that was identified as a viral disease after harvesting of the crop) [24] that occurred in the second year. Similarly, fewer numbers of pods per plant were recorded in the second year as the number of pods per plant showed a significant and positive association with plant height (Table 6). In contrast to the literature [25], the number of seeds per pod was influenced by the environment, where seeds per pod have been noted to be a component of yield that shows little variation across environments as it is linked more to genotype than to the environment.

The variety "Derash" took longer to flower and mature than the "Local cultivar." It also produced significantly taller plants, a higher number of pods per plant, a heavier 100-seed weight, and a higher grain yield than the "Local cultivar" (Table 5).

Concerning the seed rate, there was a linear and significant $(p<0.05)$ decrease in days to flowering, physiological maturity, and the number of pods per plant by 2.92 , 1.9 , and $85.35 \%$, respectively, as the seed rate increased from 40 to $140 \mathrm{~kg} / \mathrm{ha}$ (Table 5). Significantly, the highest number of seeds per pod was obtained at a seed rate of $100 \mathrm{~kg} / \mathrm{ha}$. The present findings on the number of pods per plant and the number of seeds per pod are quite similar to the results of Parveen and Bhuiya [26]. According to López-Bellido et al. 


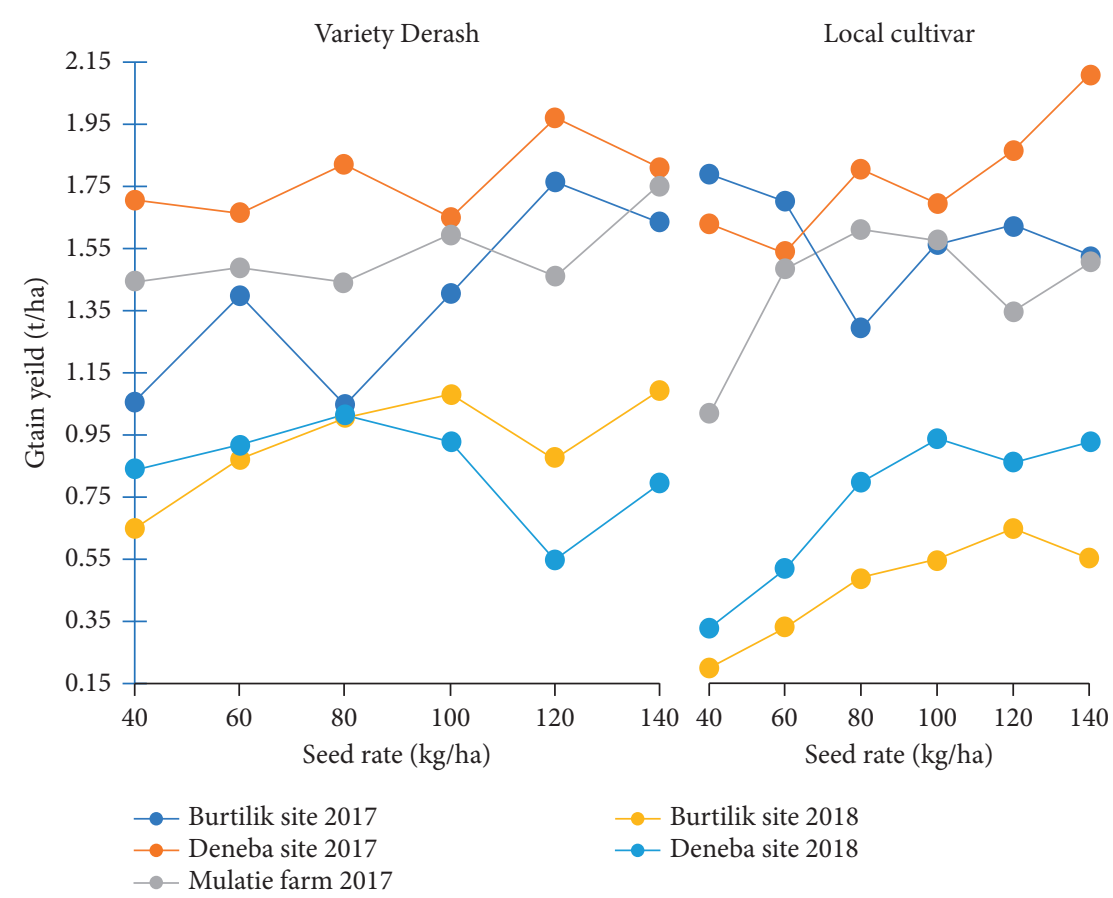

FIGURE 2: Effect of environment, variety, and seed rate on grain yield ( $\mathrm{t} / \mathrm{ha}$ ) of lentil combined over 5 environments in 2017 and 2018.

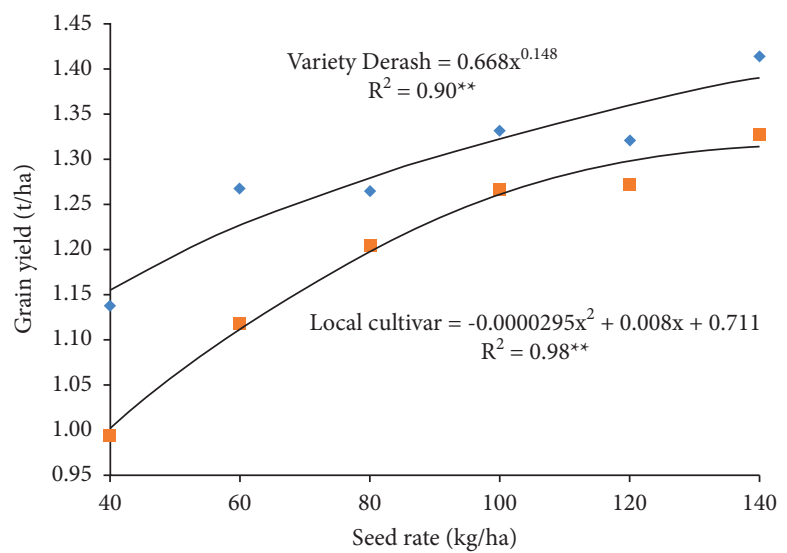

FIGURE 3: Regression equation between grain yield and seed rate for each variety (kg/ha). $X$ represents the seed rate level.

TABLE 3: Dominance and marginal rate of return analysis for the effect of varieties of different seed sizes and seed rate on grain yield ( $t / h a)$ of lentil variety "Derash" at Moretina Jiru and Siyadebrina Wayu districts, combined over 5 environments (3 locations in 2017 and 2 locations in 2018).

\begin{tabular}{|c|c|c|c|c|c|c|}
\hline Seed rate $(\mathrm{kg} / \mathrm{ha})$ & Predicted grain yield $(\mathrm{kg} / \mathrm{ha})$ & Adjusted grain yield $(\mathrm{kg} / \mathrm{ha})$ & GB (Birr/ha) & TVC (Birr/ha) & NB (Birr/ha) & MRR (\%) \\
\hline 40 & 1.15 & 1.04 & 29059.08 & 1160.00 & 27899.08 & \\
\hline 50 & 1.19 & 1.07 & 30034.79 & 1450.00 & 28584.79 & 236.45 \\
\hline 60 & 1.22 & 1.10 & 30856.27 & 1740.00 & 29116.27 & 183.27 \\
\hline 70 & 1.25 & 1.13 & 31568.32 & 2030.00 & 29538.32 & 145.54 \\
\hline 80 & 1.28 & 1.15 & 32198.40 & 2320.00 & 29878.40 & 117.27 \\
\hline 90 & 1.30 & 1.17 & 32764.60 & 2610.00 & 30154.60 & 95.24 \\
\hline 100 & 1.32 & 1.19 & 33279.52 & 2900.00 & 30379.52 & 77.56 \\
\hline 110 & 1.34 & 1.21 & 33752.28 & 3190.00 & 30562.28 & 70.29 \\
\hline 120 & 1.36 & 1.22 & 34189.74 & 3480.00 & 30709.74 & 63.81 \\
\hline 130 & 1.37 & 1.24 & 34597.17 & 3770.00 & 30827.17 & 57.98 \\
\hline 140 & 1.39 & 1.25 & 34978.72 & 4060.00 & 30918.72 & 52.70 \\
\hline
\end{tabular}

GB, gross benefit; TVC, total variable cost; NB, net benefits; MRR, marginal rate of return. 
TABLE 4: Dominance and marginal rate of return analysis for the effect of varieties of different seed sizes and seed rate on grain yield (t/ha) "Local cultivars" of lentil at Moretina Jiru and Siyadebrina Wayu districts, combined over 5 environments (3 locations in 2017 and 2 locations in 2018).

\begin{tabular}{|c|c|c|c|c|c|c|}
\hline Seed rate $(\mathrm{kg} / \mathrm{ha})$ & Predicted grain yield (kg/ha) & Adjusted grain yield (kg/ha) & GB (Birr/ha) & TVC (Birr/ha) & NB (Birr/ha) & MRR (\%) \\
\hline 40 & 0.98 & 0.89 & 26562.60 & 1240.00 & 25322.60 & \\
\hline 50 & 1.04 & 0.93 & 28005.75 & 1550.00 & 26455.75 & 365.53 \\
\hline 60 & 1.08 & 0.98 & 29289.60 & 1860.00 & 27429.60 & 314.15 \\
\hline 70 & 1.13 & 1.01 & 30414.15 & 2170.00 & 28244.15 & 262.76 \\
\hline 80 & 1.16 & 1.05 & 31379.40 & 2480.00 & 28899.40 & 211.37 \\
\hline 90 & 1.19 & 1.07 & 32185.35 & 2790.00 & 29395.35 & 159.98 \\
\hline 100 & 1.22 & 1.09 & 32832.00 & 3100.00 & 29732.00 & 108.60 \\
\hline 110 & 1.23 & 1.11 & 33319.35 & 3410.00 & 29909.35 & 57.21 \\
\hline 120 & 1.25 & 1.12 & 33647.40 & 3720.00 & 29927.40 & 31.52 \\
\hline 130 & 1.25 & 1.13 & 33816.15 & 4030.00 & 29786.15 & $\mathrm{D}$ \\
\hline 140 & 1.25 & 1.13 & 33825.60 & 4340.00 & 29485.60 & $\mathrm{D}$ \\
\hline
\end{tabular}

GB, gross benefit; TVC, total variable cost; NB, net benefits; MRR, marginal rate of return.

TABLE 5: Main effects of environment, variety, and seed rate on grain yield ( $\mathrm{t} / \mathrm{ha}$ ) and some agronomic parameters of lentil combined over 5 environments in 2017 and 2018.

\begin{tabular}{|c|c|c|c|c|c|c|c|}
\hline Treatment & DTF & DTM & Plh $(\mathrm{cm})$ & NPPP & NSPP & HSW (g) & Gy (t/ha) \\
\hline \multicolumn{8}{|l|}{ Environment } \\
\hline Burtilik site in 2017 & $53.9^{c}$ & $105.0^{\mathrm{cd}}$ & $30.2^{\mathrm{a}}$ & $47.7^{\mathrm{b}}$ & $1.5^{\mathrm{a}}$ & 3.12 & $1.48^{\mathrm{b}}$ \\
\hline Deneba site in 2017 & $54.2^{\mathrm{c}}$ & $104.7^{\mathrm{d}}$ & $31.0^{\mathrm{a}}$ & $47.9^{\mathrm{b}}$ & $1.3^{\mathrm{b}}$ & 3.19 & $1.77^{\mathrm{a}}$ \\
\hline Farmer field in 2017 & $54.5^{\mathrm{c}}$ & $105.6^{\mathrm{c}}$ & $31.0^{\mathrm{a}}$ & $54.8^{\mathrm{a}}$ & $1.5^{\mathrm{a}}$ & 3.21 & $1.48^{\mathrm{b}}$ \\
\hline Burtilik site in 2018 & $58.2^{\mathrm{a}}$ & $108.4^{\mathrm{a}}$ & $23.3^{\mathrm{c}}$ & $26.1^{\mathrm{d}}$ & $1.1^{\mathrm{c}}$ & 3.14 & $0.69^{c}$ \\
\hline Deneba site in 2018 & $56.7^{\mathrm{b}}$ & $107.6^{\mathrm{b}}$ & $26.9^{\mathrm{b}}$ & $35.4^{\mathrm{c}}$ & $1.4^{\mathrm{ab}}$ & 3.07 & $0.78^{\mathrm{c}}$ \\
\hline LSD $(5 \%)$ & 0.508 & 0.70 & 1.08 & 3.33 & 0.12 & ns & 0.104 \\
\hline \multicolumn{8}{|l|}{ Variety } \\
\hline Derash & 57.1 & 112.2 & 31.2 & 47.0 & 1.3 & 3.42 & 1.29 \\
\hline Local cultivar & 53.9 & 100.6 & 25.8 & 37.7 & 1.4 & 2.88 & 1.20 \\
\hline LSD $(5 \%)$ & 0.321 & 0.40 & 0.68 & 2.11 & ns & 0.066 & 0.066 \\
\hline \multicolumn{8}{|l|}{ Seed rate $(\mathrm{kg} / \mathrm{ha})$} \\
\hline 40 & $56.4^{\mathrm{a}}$ & $107.2^{\mathrm{a}}$ & 27.6 & $58.2^{\mathrm{a}}$ & $1.3^{\mathrm{ab}}$ & 3.15 & $1.07^{\mathrm{c}}$ \\
\hline 60 & $56.0^{\mathrm{a}}$ & $107.0^{\mathrm{a}}$ & 27.9 & $48.3^{\mathrm{b}}$ & $1.2^{\mathrm{b}}$ & 3.21 & $1.19^{\mathrm{b}}$ \\
\hline 80 & $55.6^{\mathrm{ab}}$ & $107.1^{\mathrm{a}}$ & 28.6 & $42.7^{\mathrm{c}}$ & $1.3^{\mathrm{b}}$ & 3.09 & $1.23^{\mathrm{b}}$ \\
\hline 100 & $55.1^{\mathrm{b}}$ & $105.7^{\mathrm{b}}$ & 28.8 & $38.4^{\mathrm{d}}$ & $1.5^{\mathrm{a}}$ & 3.14 & $1.30^{\mathrm{ab}}$ \\
\hline 120 & $55.0^{\mathrm{b}}$ & $105.5^{\mathrm{b}}$ & 29.1 & $35.2^{\mathrm{d}}$ & $1.3^{\mathrm{ab}}$ & 3.17 & $1.30^{\mathrm{ab}}$ \\
\hline 140 & $54.8^{\mathrm{b}}$ & $105.2^{\mathrm{b}}$ & 28.8 & $31.4^{\mathrm{e}}$ & $1.3^{\mathrm{ab}}$ & 3.12 & $1.37^{\mathrm{a}}$ \\
\hline LSD (5\%) & 0.556 & 0.80 & ns & 3.65 & 0.13 & ns & 0.114 \\
\hline Mean & 55.5 & 106.3 & 28.5 & 42.4 & 1.3 & 3.15 & 1.24 \\
\hline $\mathrm{CV}(\%)$ & 2.00 & 1.40 & 8.13 & 16.80 & 18.70 & 7.10 & 17.90 \\
\hline
\end{tabular}

DTF, days to flower; DTM, days to mature; NPPP, number of pods per plant; NSPP, number of seeds per pod; Plh, plant height; HSW, hundred seed weight; Gy, grain yield.

TABLE 6: Pearson's correlation coefficients between lentil grain yield and other studied characters, combined over 5 environments in 2017 and 2018 .

\begin{tabular}{|c|c|c|c|c|c|c|c|}
\hline & DTF & DTM & Plh & NPPP & NSPP & HSW & GY \\
\hline $\begin{array}{l}\text { DTF } \\
\text { DT }\end{array}$ & - & & & & & & \\
\hline DTM & $0.7588^{* *}$ & - & & & & & \\
\hline Plh & $-0.1248^{\mathrm{ns}}$ & $0.328^{* *}$ & - & & & & \\
\hline NPPP & $-0.0782^{\mathrm{ns}}$ & $0.1667^{*}$ & $0.5164^{* *}$ & - & & & \\
\hline NSPP & $-0.2196^{* *}$ & $-0.1037^{\mathrm{ns}}$ & $0.1225^{\mathrm{ns}}$ & $0.045^{\mathrm{ns}}$ & - & & \\
\hline HSW & $0.4225^{* *}$ & $0.6869^{* *}$ & $0.4691^{* *}$ & $0.2632^{* *}$ & $-0.0159^{\mathrm{ns}}$ & - & \\
\hline GY & $-0.5076^{* *}$ & $-0.15^{*}$ & $0.6041^{* *}$ & $0.4024^{* *}$ & $0.1718^{*}$ & $0.1679 *$ & - \\
\hline
\end{tabular}

DTF, days to flower; DTM, days to mature; Plh, plant height; NPPP, number of pods per plant; NSPP, number of seeds per pod; HSW, hundred seed weight; GY, grain yield. 
[25], under most environmental conditions, the number of pods per plant decreases with increasing density, compensating for the number of plants per square meter. The decrease in the number of pods per plant is due to a reduction in the number of stems per plant at higher densities. Plant height and 100-seed weight were not affected by seed rate (Table 5). Parveen and Bhuiya [26] reported a nonsignificant effect of seed rate on plant height and 1000 seed weight. Contrary to this result, Singh et al. [27] reported that increasing plant density increased the plant height of boldseeded lentils.

In general, as given in Table 6 , there was a positive and significant $(p<0.001)$ correlation between grain yield and each of the following: plant height, number of pods per plant, as well as number of seeds per pod and hundred seed weight. On the other hand, there was a negative and significant $(p<0.001)$ association between grain yield and each of the days to flowering and days to physiological maturity. This result reflected the importance of plant height, number of pods per plant, number of seeds per pod, and hundred seed weight in determining grain yield in the study areas. In line with this result, Tadele et al. [28] reported the presence of a positive association between grain yield and plant height of lentils on the Vertisols at Sinan. Similarly, Jawad et al. [29] reported a negative, nonsignificant correlation between grain yield and days to flowering and days to physiological maturity of lentils.

\section{Conclusions}

In this study, significant variation was observed between the varieties and among the seed rates tested for most of the parameters considered. Besides, environmental variation seemed significant due to sporadic unidentified disease incidence in the second year, resulting in lower yields. Depending on the ANOVA and economic analysis results, a seed rate of $100 \mathrm{~kg} / \mathrm{ha}$ was found sufficient for the production of both varieties of lentils. However, producers who have limited access to resources could use a seed rate of $90-50 \mathrm{~kg} / \mathrm{ha}$ in that order as an option for the broadcast sowing of lentil varieties on the highland Vertisols of the Moretina Jiru and Siyadebrina Wayu districts and similar areas under the broad bed and furrow production system.

\section{Data Availability}

The data used to support the findings of this study are available from the corresponding author upon request.

\section{Conflicts of Interest}

The authors declare that there they have no conflicts of interest.

\section{Acknowledgments}

The authors would like to thank Amhara Region Agricultural Research Institute, Debre Brehan Research Center, for financial and logistical support.

\section{References}

[1] P. Kraska, S. Andruszczak, E. Kwiecińska-Poppe, M. Staniak, K. Różyło, and H. Rusecki, "Supporting crop and different row spacing as factors influencing weed infestation in lentil crop and seed yield under organic farming conditions," Agronomy, vol. 10, no. 1, p. 9, 2020.

[2] CSA, "Agricultural sample survey 2019/20 (2012 E.C). Report on area and production of major crops," Statistical Bulletin 587, CSA (Central Statistical Agency), Addis Ababa, Ethiopia, 2020.

[3] DZARC, Released Lentil Varieties Production Package (Amharic Version) Leaflets, Debre zeit Agricultural Research Center, Debre Zeit, Ethiopia, 1997.

[4] F. Mulugeta, "Ethiopia commodity exchange authority lentil production, supply, demand and marketing issues in Ethiopia," 2009, https://www.academia.edu/36118584/ECEA_ Economic_Analysis_Department_Ethiopia_Commodity_ Exchange_Authority_Lentil_Production_Supply_Demand_ and_Marketing_issues_in_Ethiopia.

[5] M. Nigussie, A. Girma, C. Anchala, and A. Kirub, Improved Technologies and Resource Management for Ethiopian Agriculture, RCBP-MoARD, Addis Ababa, Ethiopia, A Training Manual, 2009.

[6] M. A. Jabbar, M. A. M. Saleem, S. Gebreselassie, and H. Beyene, "Role of knowledge in the adoption of new agricultural technologies: an approach and an application," International Journal of Agricultural Resources, Governance and Ecology, vol. 2, no. 3/4, pp. 312-327, 2003.

[7] A. Astatke, M. A. Mohamed Saleem, and A. El Wakeel, "Soil water dynamics under cereal and forage legume mixtures on drained Vertisols in the Ethiopian highlands," Agricultural Water Management, vol. 27, no. 1, pp. 17-24, 1995.

[8] G. Agegnehu, "Cool-season food legumes research on the highland vertisols of Ethiopia," in Proceedings of the International Symposium on Vertisols Management, P. Dubale, A. Dibabe, A. Zeleke, G. Ayele, and A. Kirub, Eds., pp. 171-183pp. 171-Advances in Vertisols Management in the Ethiopian Highlands, Debre Zeit, Ethiopia, November 2001.

[9] A. Saleem, M. A. Zahid, H. I. Javed, M. Ansar, R. Saleem, and N. Saleem, "Effect of seeding rate on lentil (lens culinaris medik) seed yield under rainfed conditions," Pakistan Journal of Agricultural Research, vol. 25, no. 3, 2012.

[10] J. P. Singh, S. Sandeep, P. Kedar, and S. N. Verma, "Effect of sowing method, seed rate and fertilizer on grain yield of lentil," Progressive Agriculture, vol. 2, no. 2, pp. 187-188, 2002.

[11] K. L. Morrison and F. J. Muehlbauer, "“Brewer" lentils," U. S. Department of Agriculture, Agriculture Research Services, Washington, D.C., WA, USA, Technical Bulletin No. 1408, 1986.

[12] K. H. M. Siddique, S. P. Loss, K. L. Regan, and D. L. Pritchard, "Adaptation of lentil (Lens culinaris Medik) to short season Mediterranean-type environments: response to sowing rates," Australian Journal of Agricultural Research, vol. 49, no. 7, pp. 1057-1066, 1998.

[13] G. Mitiku, "Review on agronomic practices for improving production and productivity of lentil in Ethiopia," Journal of Biology, Agriculture and Healthcare, vol. 6, no. 13, pp. 102106, 2016.

[14] INFO ARARI, Amhara Agricultural Research Institute (ARARI) Biometrics and Information Technology Management Unit, INFO ARARI, Bahir Dar, Ethiopia, 2004.

[15] A. S. Rutherford, A. N. Odero, and R. L. Kruska, "The role of the broad bed maker plough in Ethiopian farming systems: an 
ex post impact assessment study," ILRI Impact Assessment Series 7, ILRI (International Livestock Research Institute), Nairobi, Kenya, 2001.

[16] P. Hazelton and B. Murphy, Interpreting Soil Test Results: What Do All the Numbers Mean?, CSIRO Publishing, Clayton, Australia, 2nd edition, 2007.

[17] T. Tadese, Soil, Plant, Water, Fertilizer, Animal Manure and Compost Analysis, International Livestock Research Center for Africa, Addis Ababa, Ethiopia, Working Document, no. $13,1991$.

[18] FAO (Food and Agriculture Organization), Plant Nutrition for Food Security: A Guide for Integrated Nutrient Management, FAO, Fertilizer, and Plant Nutrition Bulletin 16, Rome, Italy, 2006.

[19] SAS Software version 9.0, copyright (c) 2002 by SAS Institute Inc. Cary, NC, USA.

[20] K. A. Gomez and A. A. Gomez, Statistical Procedure for Agricultural Research, John Wiley \& Sons, Hoboken, NJ, USA, 2nd edition, 1984.

[21] CIMMYT, From Agronomic Data to Farmer Recommendations: An Economics Training Manual, Completely Revised Edition, Centro internacional de mejoramiento de maiz y Trigo; International Maize and Wheat Improvement Center, Mexico City, Mexico, 1988.

[22] M. Tamrat, "Yield and yield components response of tef (eragrostis tef) varieties to seed rates in the highland vertisols of north Shewa, Ethiopia," Journal of Natural Sciences Research, vol. 9, no. 13, pp. 47-52, 2019.

[23] A. Molla, "Farmer's knowledge helps develop site specific fertilizer rate recommendations, central highlands of Ethiopia," World Applied Sciences Journal, vol. 22, no. 4, pp. 555-563, 2013.

[24] S. G. Kumari, R. Larsen, K. M. Makkouk, and M. B. Muhammad Bashir, "Virus diseases and their control," in The Lentil Botany, Production and Uses, W. Erskine, F. J. Muehlbauer, A. Sarker, and B. Sharma, Eds., CAB International, Wallingford, UK, pp. 306-325, 2009.

[25] F. J. López-Bellido, L. López-Bellido, and R. J. López-Bellido, "Competition, growth and yield of faba bean (Vicia faba L.)," European Journal of Agronomy, vol. 23, no. 4, pp. 359-378, 2005.

[26] K. Parveen and M. S. U. Bhuiya, "Effect of method of sowing and seed rate on the yield and yield components of lentil," Journal of Agroforestry and Environment, vol. 4, no. 1, pp. 155-157, 2010.

[27] O. N. Singh, M. Sharma, and R. Dash, "Effect of seed rate, phosphorus and FYM application on growth and yield of bold seeded lentil," Indian Journal of Pulses Research, vol. 16, no. 2, pp. 116-128, 2003.

[28] T. Tadele, L. Teshome, M. Behailu, and S. Gashaw, "Correlation and path coefficient analysis of yield and yield components in lentil (Lens culinaris Medik.) germplasm in the highlands of Bale, Ethiopia," International Journal of Biodiversity and Conservation, vol. 6, no. 1, pp. 115-120, 2014.

[29] M. Jawad, S. R. Malik, M. A. Sarwar, M. Asadullah, I. Hussain, and R. Khalid, "Genetic analysis of lentil (lens culinaris) exotic germplasm to identify genotypes suitable for mechanical harvesting," Pakistan Journal of Agricultural Research, vol. 32, no. 1, pp. 152-158, 2019. 